\title{
Sciendo
}

Environmental \& Socio-economic Studies

DOI: $10.2478 /$ environ-2019-0020

Environ. Socio.-econ. Stud., 2019, 7, 4: 17-25

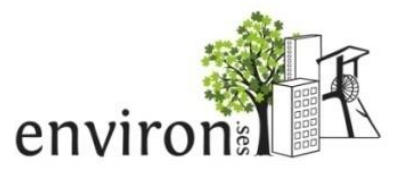

(C) 2019 Copyright by University of Silesia in Katowice

Original article

Service connections of the Katowice conurbation cities

\section{Franciszek Kłosowski}

Institute of Social and Economic Geography and Spatial Management, University of Silesia in Katowice, Sosnowiec, Będzińska Str. 60, Poland

E-mail address: franciszek.klosowski@us.edu.pl

ORCID iD: https://orcid.org/0000-0003-2806-0403

\begin{abstract}
The study attempts to determine the service connections of the cities of the Katowice conurbation. The analysis was based on surveys conducted among 845 residents representing all cities in the conurbation, who were asked about using services in other cities. The collected material allowed the author to state that the practice of using services outside their place of residence, in other cities, is quite common, as $63 \%$ of respondents do so. The cities of the conurbation have a different impact on other centres, which allowed us to determine the service hierarchy of the conurbation cities. In all but one city, the inhabitants most often indicated that they used services located in Katowice, thus as the only city used this has an impact covering the entire Katowice conurbation. Seven other cities (Bytom, Chorzów, Dąbrowa Górnicza, Gliwice, Sosnowiec, Tychy and Zabrze) demonstrate sub-conurbation influences, which are mainly limited to neighbouring cities. The impact of cities within a mini-conurbation (4 cities) and a micro-conurbation ( 5 cities) were also identified. These have a limited impact on neighbouring centres, but, only in selected service areas. The collected information indicates that the inhabitants of the conurbation most often go to another city for commercial and cultural purposes and in connection with practising sports and recreation.
\end{abstract}

KEY WORDS: services, service connections, Katowice conurbation, hierarchy of service centres

ARTICLE HISTORY: received 24 June 2019; received in revised form 23 October 2019; accepted 13 November 2019

\section{Introduction}

Each operating service establishment generates a certain area of influence identified with the area of residence (individual customers) or the location of business entities (institutional customers) using its services. Many different factors affect the extent of spatial interactions. In the most general terms, it can be assumed that the basic facilities that are often used are characterised by low centrality and the area of impact. As the order of services increases, the spatial extent of the impact increases. Other important factors that cause an increase in spatial impact are: the quality of the service provided, the prestige of the facility, marketing activities, e.t.c. As a result, some services may cross the borders of cities, provinces, and the country, reaching international or even global coverage (financial, stock exchange, media services, e.t.c.). Knowledge of the impacts is very important because it allows us to learn about the functioning of the services, and thus also to implement an appropriate policy in relation to individual types or the entire system of services within spatial systems (cities, provinces, country).

There are at least a few theoretical concepts regarding the city's impact on its surroundings. Undoubtedly, such classic approaches are already the theory of economic base or the central place theory by CHRISTALLER (1933). In the economic base theory, the economic sphere of the city is divided into two parts - exogenous (external) base, which, affects the environment, has primarily a city-forming character, and an endogenous (internal) base affecting the city's residents. It is the exogenous functions that affect the size of the 
spatial interactions. The theory somewhat related to the economic base theory, but having a spatial character, is the central place theory in which cities exhibit diverse impacts, a hierarchy which depends on the excess of economic importance (mainly of a service nature) in particular types of cities (which is a kind of exogenous function). Newer concepts that appeared in the 1990s (CAMAGNI, 1993; BATTEN, 1995) put the main emphasis on network connections (MEIERS, 2007a, b). The network model is focused on horizontal and non-hierarchical relationships between cities of a complementary nature, especially in relation to polycentric systems (CAMAGNI \& SALONE, 1993). However, as VAN DER KNAAP (2002) points out, a feature of this model, unlike the central place theory, is also a variable set of functions at the same level of cities.

Studies on the impact of cities (urban complexes) have a long tradition in Poland. However, their authors approached this issue very differently in terms of methodology. Most often, this type of research took into account a set of many socioeconomic measures. This approach was used to determine particular aspects e.g. the sizes of urban agglomerations. This type of research includes works by: IWANICKA-LYRA (1969), GONTARSKI (1980), LESZCZYCKI ET AL. (1971), MALISZ ET AL. (1972), HOŁOWIECKA (2004), SMĘTKOWSKI (2007), KRZYSZTOFIK, RUNGE \& SPÓRNA (2011), HEFFNER \& GIBAS (2014).

On the other hand, EBERHARDT (1970), SOBALAGWOSDZ (2007), KOMORNICKI ET AL. (2013) or GUZIK \& KoŁoś (eds.) (2015) conducted multi-faceted research on the functional and spatial links among Polish cities. Another direction of research was to determine the impact of cities (city) by commuting (including STREFY WPEYWU..., 1971; POTRYKOWSKA, 1983; GOCAE \& RAKOWSKI, 1991; RUNGE, 1991; HOŁOWIECKA, 2002; ŚLESZYŃSKI, 2013; BUL \& WALASZEK, 2015). AS RAKOWSKA (2015) points out, commuting is also the basis for delimiting areas in the USA and Canada. In the literature, one can also find works in which the influences were related to services, however, most often it was done in a narrow scope of individual types of services, e.g. education, and especially higher education.

The first such works were already published in the 1930s (KSIĄŻKóWNA, 1932; ORMICKI, 1932; WITTLINOWA, 1937), and a wider interest in this issue appeared in the post-war period, although, as noted by ILNICKI (2014), these studies were considered on the basis of interest in the geography of cities (ENDRUKAJTIS, 1957; KREMKYSALONI, 1957; ROMAHN-KWIATKOWSKA, 1957; etc.). The mainstream of this type of research was focused on the impact of universities on a national scale (WRóBEL, 1951; DZIEWOŃSKI \& IWANICKA, 1961; CHOJNICKI \& CZYŻ, 1997; HERBST, 2009, 2012), as well as on the analysis of the impact of individual universities (TOMCZYK, 1987; MOLENDA, 1996; SZYMAŃSKA ET AL., 1998; KULCZYŃSKA, 2004; BOROWIEC, 2006, 2007; ILNICKI, 2008; HERBST, 2012; etc.) or even selected fields of study within the university (BOROWIEC, 2000; HIBSZER ET AL., 2009). Apart from universities, similar studies were also applied to secondary education (JEŚMAN, 1961; PALONKA, 1965, 1971).

Educational influences were the basis for determining the spatial impact of cities or agglomerations, e.g. Opole (JEŚMAN, 1961), Tarnów (PALONKA, 1971) or the Poznań agglomeration (CZYŻ ET AL., 1996). Similar works were also carried out in Europe (SÁ ET AL., 2004; ChrISTIE, 2007; DuKE-WiLIAMS, 2009) and the United States (Аввот \& SMITH, 1975; KYUNG, 1996; MiXON \& HSING, 1996; BELFILD \& MORRIS, 1999; BARYLA \& DETTERWEICH, 2001; AL \& WINTERS, 2009).

More extensive research on the functional and spatial organisation of polycentric settlement systems, especially in the context of their network connections, was carried out, among others, for the Randstadt region in the Netherlands (MEIJERS, 2005, 2008; BURGER ET AL., 2013), the Ruhr in Germany and the Flemish Diamond in Belgium (DIELMAN \& FALUDI, 1998; MEIJERS, 2007b), or other polycentric regions in Europe (HALL \& PAIN, 2006).

As noted by BURGER ET AL. (2013), spatial organisation in relation to various functional connections is not identical and, as the research in the Randstadt region shows, they depend on the kind of lens through which they are examined. They will be slightly different depending on whether commuting to school, trade or business connections are taken into account. On the other hand, comparative studies in the Randstadt region, the Flemish Diamond and the Ruhr show a different level of complementarity (network character) in these systems, which is higher in the case of Randstadt and the Flemish Diamond than in relation to the Ruhr. But the level of complementarity in these first two regions is also decreasing (MEIJERS, 2007b).

In this context, it seems interesting to analyse the connections in relation to services in a polycentric region such as the Katowice conurbation (Poland).

\section{Research methods}

The main problem of this kind of research is the difficulties in obtaining relevant data. They are missing in official statistics, and there are also big problems with obtaining statistical information 
from other sources (HERBST, 2012). The vast majority of research on the impact of cities in the context of services was based on the analysis of the places of residence of people using the service (e.g. pupils, students). This is undoubtedly the most precise research method, however, such an approach is difficult to implement nowadays, especially with regard to the scope going beyond individual types of services and the conurbation system, due to a few facts, i.e.

1) firstly - it is a labour-intensive approach due to the very large number of facilities that may have a wider spatial impact and a larger number of cities forming the conurbation,

2) secondly - it is difficult to isolate all institutions that have a wider spatial impact. Obviously, such impact applies to higher and specialist institutions, but also includes parts of basic facilities that, due to the quality of the provided services, location or favourable accessibility to transportation, may have impact beyond the standards for given types of activity (KŁosowsKI, 1996). A good example are upper secondary schools, which are common in a larger number and in all cities of the Katowice conurbation; however, research (ANALIZA POWIĄZAŃ FUNKCJONALNYCH... 2012) showed that in the school year 2011/2012, 11,100 students (i.e. 9\% of the total) attended a school located not in their own city but outside of it. Interestingly, the most, over 2,000 students, commuted to Chorzów (1,800 students to Katowice).

3) thirdly - there are few facilities that keep records of the fact of providing a service in the form of address data (e.g. hotels, libraries, schools, service centres), and in addition these materials are difficult to access due to the restrictions arising from GDPR (general data protection).

Attempts are also being made to use social media for this purpose, especially the once-popular Nasza Klasa portal (BAJERSKI, 2008; HERBST, 2012). Problems with obtaining relevant personal data, as well as the anonymity of using many services, forces researchers to use surveys. These surveys can be direct (survey of specific facilities) or indirect (survey questions related to a greater number of facilities). Considering these conditions, in this study it was decided to determine the relationships on the basis of indirect surveys, where respondents of the survey: 1) declared whether they used services outside their place of residence, 2) indicated the cities and facilities they used to meet their service needs and 3) determined the frequency of the use of services in other cities.

Due to the fact that the survey was directed only at individual people, the results mainly reflect the impact on services of the population. Services for producers and businesses are characterised by slightly different criteria for choosing cooperating service outlets.

\section{Results of the study}

The conurbation already has a special predisposition to strong interactions between the cities within it, because as is indicated in their definitions by DZIEWOŃSKI (1956) or LISZEWSKI (2008), it is a set of cities adjacent to each other among which there is no main centre, they are characterised by a coordination of centres. Given the diverse size of the centres that make up the conurbation, as well as their slightly different functional structure and the degree of restructuring of their economy, these cities complement their functions, which in turn leads to multiple connections among them. It is no different in the Katowice conurbation. According to the KRZYSZTOFIK, RUNGE \& SPÓRNA (2011) delimitation, the core of the Katowice conurbation includes 17 cities of the central part of the Silesian Province covering an area of $1355 \mathrm{~km}^{2}$ and is inhabited by about 2 million people. Individual cities differ significantly in size, administrative functions and level of service development (Table 1).

Exploratory surveys were conducted in July between 2015-2018 and covered a randomly selected 845 people. They were carried out in all cities of the conurbation. 55-60 surveys were completed in each large city, and 35-40 surveys in each medium-sized city. Most of the respondents were women, who constituted $55 \%$ of the total number of respondents (Fig. 1).

The respondents represented all age groups (Fig. 2), with the youngest being the most numerous group. People aged 20-39 accounted for almost half of the total number of respondents (47\%). The percentage of other age groups was even, ranging from 9 to $13 \%$.

In terms of the structure of education, the most numerous group constituting nearly half of the respondents, were persons representing secondary education (Fig. 3). People with basic vocational and higher education also constituted large groups.

The legitimacy of the issues raised is evidenced by the fact that as many as $63 \%$ of respondents indicated that they used services not only located in their city of residence, but also in other cities of the conurbation. However, this percentage varied considerably in individual cities. The highest percentage of people using services in other cities was achieved in Dąbrowa Górnicza (95\%), Świętochłowice (93\%) and Czeladź (92\%). That is, 
as a rule, in medium-sized cities (except for Dąbrowa Górnicza) and with a clearly weaker level of service development (Table 1). In turn, the inhabitants of Gliwice (30\% of respondents), Siemianowice Śląskie (43\%), Ruda Śląska (44\%), Sosnowiec (45\%) and Katowice (48\%), and therefore most often residents of the largest conurbation cities with an extensive service base, use the opportunity least often. Most respondents quite intensively used the opportunities offered by services in other cities, because $70 \%$ of this group used such services at least once a week, and nearly half declared that it was several times a week (Fig. 4).

Table 1. Characteristics of the cities of the Katowice conurbation in 2018 (Source: Own study based on the Statistics of Poland' Local Data Bank, Silesian Province. Sub-regions, districts, communes. Statistical Office in Katowice and Zuzańska-Żyśko, 2016)

\begin{tabular}{|c|c|c|c|c|c|c|c|}
\hline No. & Cities & $\begin{array}{l}\text { Administrative } \\
\text { functions }\end{array}$ & $\begin{array}{c}\text { Number of } \\
\text { residents } \\
\text { (in thousands) }\end{array}$ & $\begin{array}{c}\text { Persons } \\
\text { employed } \\
\text { in services } \\
\text { per } 1,000 \\
\text { inhabitants }\end{array}$ & $\begin{array}{l}\text { REGON business } \\
\text { entities from the } \\
\text { scope of services } \\
\text { per } 1,000 \\
\text { inhabitants }\end{array}$ & $\begin{array}{c}\text { Upstream } \\
\text { service } \\
\text { institutions } \\
\text { acc. to } \\
\text { Zuzańska- } \\
\text { Żyśko (2016) }\end{array}$ & $\begin{array}{c}\text { Metropolitan } \\
\text { institutions and } \\
\text { services in } \\
\text { accordance with the } \\
\text { centrality coefficient Cj } \\
\text { acc. to Zuzańska- } \\
\text { Żyśko (2016) }\end{array}$ \\
\hline 1 & Katowice & SW & 294.5 & 451 & 136 & 1,180 & 1.00 \\
\hline 2 & Sosnowiec & mpp & 202.0 & 176 & 92 & 319 & 0.36 \\
\hline 3 & Gliwice & mpp & 179.8 & 269 & 110 & 413 & 0.65 \\
\hline 4 & Zabrze & mpp & 173.4 & 151 & 79 & 174 & 0.35 \\
\hline 5 & Bytom & mpp & 166.8 & 129 & 80 & 196 & 0.17 \\
\hline 6 & Ruda Śl. & $\mathrm{mpp}$ & 138.0 & 115 & 58 & 95 & 0.20 \\
\hline 7 & Tychy & mpp & 127.8 & 181 & 89 & 248 & 0.37 \\
\hline 8 & Dąbrowa Górnicza & mpp & 120.3 & 162 & 80 & 154 & 0.23 \\
\hline 9 & Chorzów & mpp & 108.4 & 191 & 84 & 193 & 0.50 \\
\hline 10 & Jaworzno & mpp & 91.6 & 131 & 74 & 102 & 0.04 \\
\hline 11 & Mysłowice & $\mathrm{mpp}$ & 74.6 & 123 & 77 & 121 & 0.20 \\
\hline 12 & Siemianowice Śl. & mpp & 67.2 & 117 & 73 & 126 & 0.14 \\
\hline 13 & Tarnowskie Góry & $\mathrm{mp}$. & 61.4 & 186 & 102 & - & 0.19 \\
\hline 14 & Będzin & $\mathrm{mp}$. & 56.8 & 141 & 96 & - & 0.04 \\
\hline 15 & Piekary Śl. & mpp & 55.3 & 128 & 63 & 41 & 0.10 \\
\hline 16 & Świętochłowice & mpp & 50.0 & 102 & 62 & 54 & 0.11 \\
\hline 17 & Czeladź & bfa & 31.7 & 104 & 79 & - & 0.11 \\
\hline
\end{tabular}

Explanation: - no data; sw - capital of the province; mpp - city with district rights; mp - district city; bfa - city without administrative functions

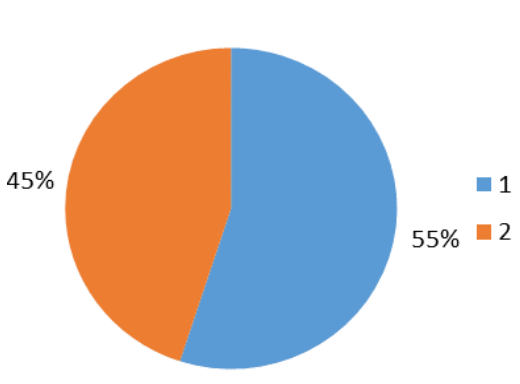

Fig. 1. Gender structure of the survey's respondents (Source: own study) Explanation: 1 - women, 2 - men

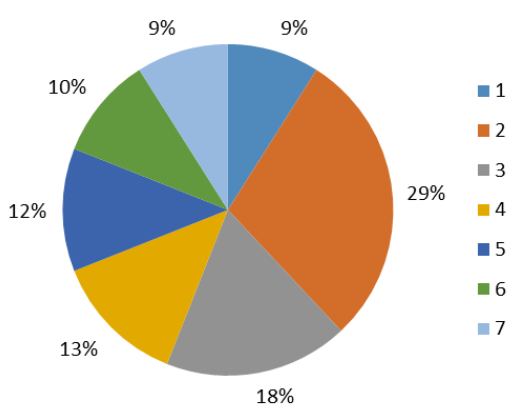

Fig. 2. Age structure of the survey's respondents (Source: own study) Explanation: 1 - up to 19 years, 2 - 20-29, 3 - 30-39, 4-40-49, 5 - 50-59, 6 - 60-69, $7-70$ and over

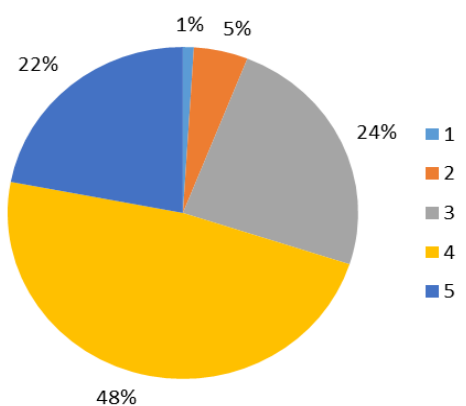

Fig. 3. Education structure of the survey's respondents (Source: own study)

Explanation: 1 - basic, 2 - junior high school, 3 - basic vocational, 4 - secondary, 5 - higher

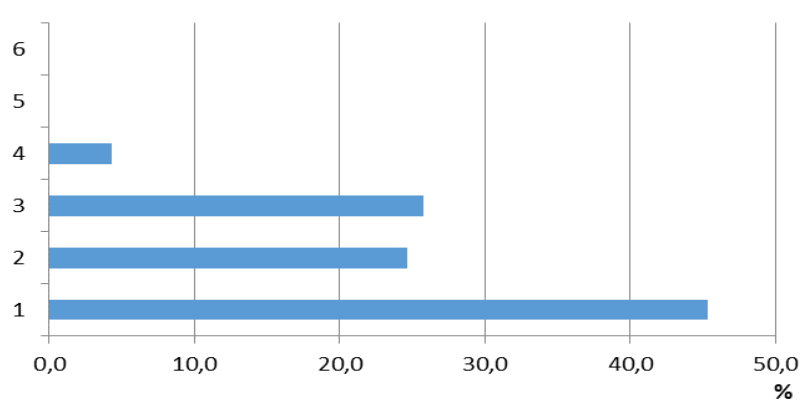

Fig. 4. Frequency of using services in other cities of the conurbation (Source: own study)
Explanation: 1 - a few times a week, 2 - once a week, 3 - 1-2 times a month, 4 - once every few months, 5 - once a year, 6 - less than once a year

When analysing in which cities the conurbation inhabitants most often use services, a fairly clear picture appears. In all cities (except for one), the inhabitants most often indicated that they used services located in Katowice. Therefore, Katowice is treated as the city of first choice when it comes to using services outside the place of residence (Fig. 5a). 

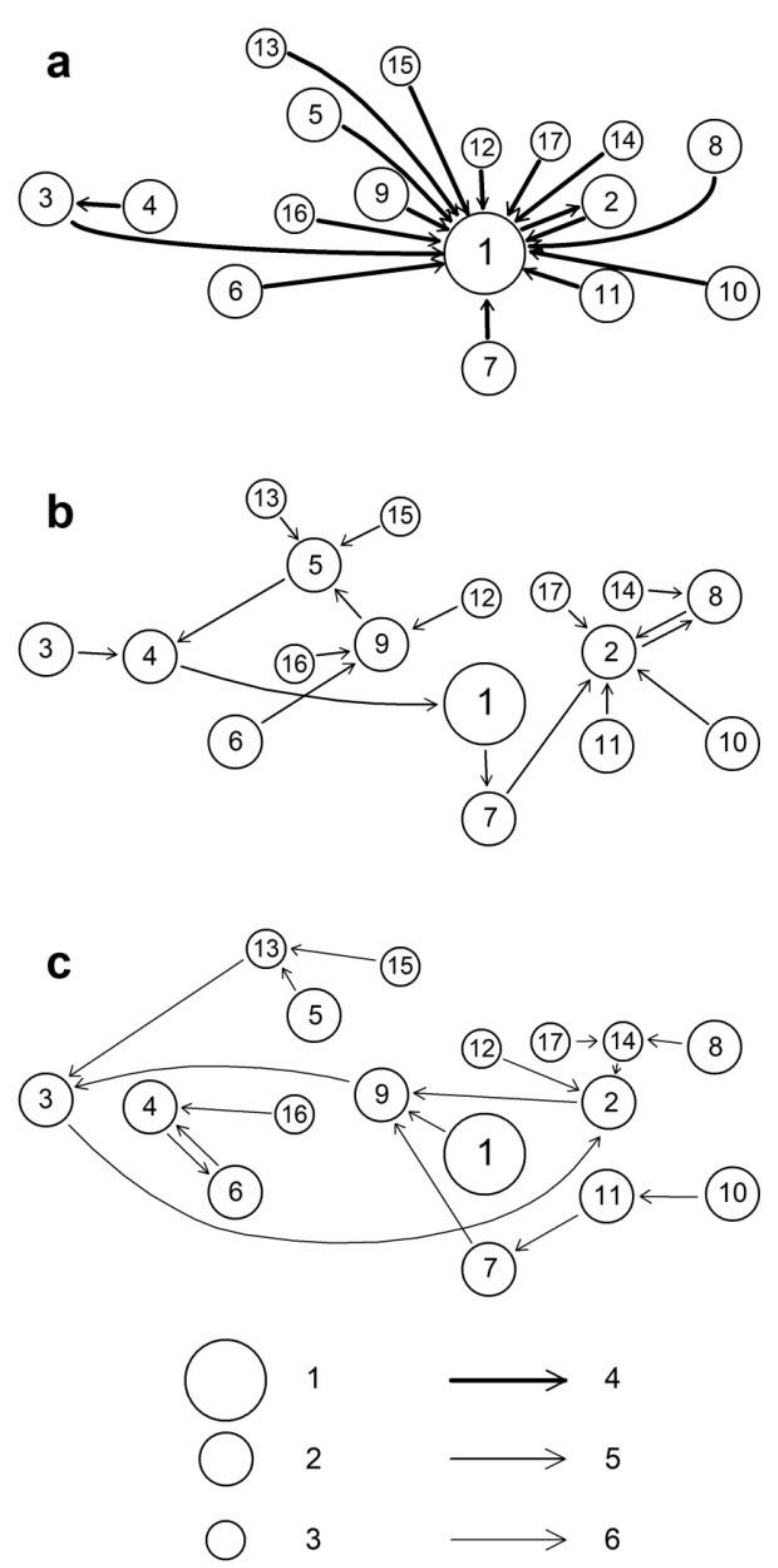

Fig. 5. Service connections of cities within the Katowice conurbation (Source: own study)

Explanation: a - 1st order connection, b - 2nd order connections, c - 3rd order connections. The numbers inside the circles correspond to the names of the cities: 1 Katowice, 2 - Sosnowiec, 3 - Gliwice, 4 - Zabrze, 5 - Bytom, 6 - Ruda Śl., 7 - Tychy, 8 - Dąbrowa Górnicza, 9 - Chorzów, 10 - Jaworzno, 11 - Mysłowice, 12 - Siemianowice, 13 Tarnowskie Góry, 14 - Będzin, 15 - Piekary Śl., 16 Świętochłowice, 17 - Czeladź.

1 - capital of the province, 2 - large cities, 3 - medium-sized cities, 4 - cities' 1 st order connections, 5 - cities' 2 nd order connections, 6 - cities' 3 rd order connections

The share of Katowice in these indications ranged from $24 \%$ in Ruda Śląska to $70 \%$ in the case of Mysłowice. In five further cities, the percentage of indications for Katowice exceeded 50\% (Chorzów, Tychy, Siemianowice Śląskie, Czeladź, Dąbrowa Górnicza). The relatively low share of Katowice in the indications in Ruda Śląska results from the large service role of other cities. Next in order were Chorzów, Zabrze, Gliwice, Świętochłowice and Bytom with shares of $21 \%, 18 \%, 17 \%, 12 \%$ and $8 \%$ respectively. Zabrze is the only city where Katowice is not indicated as the main place for satisfying the needs for services outside the place of residence. Here, the neighbouring Gliwice (38\%) received the most indications, although Katowice was in second place with a share of $32 \%$.

Considering the 2nd order service connections (Fig. 5b), the role of most major cities is visible. In this approach, the impact of distance is clearly visible, because most often the influences relate to the nearest cities. The role of Sosnowiec, to a lesser extent of Dąbrowa Górnicza in the eastern part of the conurbation, Chorzów in the central part, and Bytom and Zabrze in the western part of the conurbation is clearly visible. This group also includes Gliwice, which is even more important for the inhabitants of Zabrze than Katowice. Figure 5c shows only weaker links, which also more closely connect with further centres, as is the case of Gliwice and Tychy. In this approach, local centres in the form of Będzin and Tarnowskie Góry, are visible.

It is also important to determine which types of facilities generate wider spatial impacts. It turns out that most often the inhabitants of the conurbation go to another city for commercial purposes, i.e. to do their shopping (Fig. 6). This applies to trade as such, but many people pointed to shopping trips in shopping centres that are not found in all conurbation cities. The region's largest Silesia City Centre shopping centre plays a special role here; it is annually visited by about 15 million people, of course not only from Katowice, but also from other conurbation cities or towns of the Silesian Province.

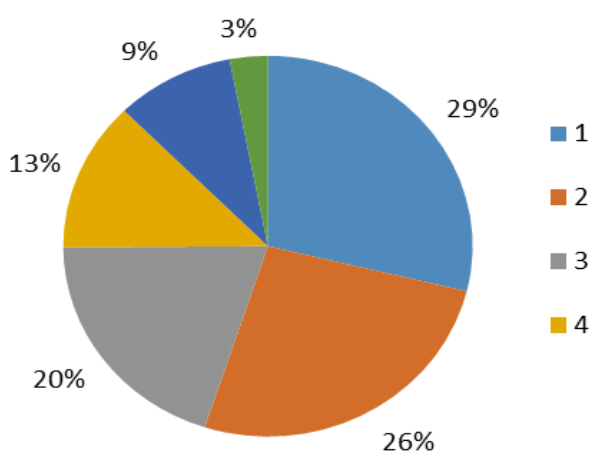

Fig. 6. Service outlets most often used by residents in other cities of the Katowice conurbation (Source: own study)

Explanation: 1 - trade, 2 - culture, 3 - sport end recreation, 4 - healthcare, 5 - education, 6 - other

Cultural institutions - cinemas, theatres, galleries and libraries - where in second place. Also in this case, not all such facilities are found in every conurbation city, which obviously 
encourages trips to meet cultural needs. Next in order were sports and recreation facilities (especially water parks), health care and education (schools, universities).

\section{Discussion of results}

The presented information indicates that it is normal for the inhabitants of the Katowice conurbation to satisfy their service needs not only in their city of residence, but also in other cities of the conurbation. Thus, the lower level of development of services, characteristic of smaller cities, admittedly slightly hinders, but does not deprive their residents of the opportunity to use a wide range of services, including upstream and highly specialised services.

The surveys unequivocally indicated that Katowice played a primary role in satisfying the service needs of most residents of the Katowice conurbation. This domination of Katowice is the result of the most extensive and diverse structure of services that perform exogenous function to a large extent (GWOSDZ, 2004, 2014; KŁOSOWSKI, 2008; GWOSDZ \& SOBALA-GWOSDZ, 2012). As ZUZAŃSKAŻYŚKo (2016) note, Katowice is also a place with a concentration of metropolitan services which are important for the development and shaping of functions such as: FIRE services ( $F$ - finance, $I$ - insurance, $R E$ - real estate), advanced production services (APS), modern business services (outsourcing, shared services, research and development) or, more broadly, the creative sector. This is clearly visible in relation to metropolitan institutions and services in which Katowice is the only city to have achieved the centrality coefficient $\mathrm{C}$ of 1.00 , which means that in this city there are all the metropolitan institutions and services analysed by ZUZAŃSKA-ŻYŚKO (2016) (11 in total). This situation is the result of, among others, the size of the city, the functions of the provincial centre, the central location in the conurbation, the centripetal transport system of the conurbation, or the fact of being the largest labour market in the region with the largest number of commuting to work (ANALIZA POWIAZZAN FUNKCJONALNYCH..., 2012; SITEK ET AL., 2013). However, one should be aware that admittedly Katowice dominates in services, but many important facilities are also located in other cities, especially the large ones, including: Silesian University of Technology, many scientific institutes and the Oncology Centre are located in Gliwice, the leading cardiological centre the Silesian Centre for Heart Diseases is located in Zabrze, the Silesian Opera or the Silesian Dance Theatre in Bytom, the Rozrywka Theatre, the Planetarium and the Silesian Garden are in Chorzów. When one wants to use the services of a water park, one must go to Dąbrowa Górnicza, Tarnowskie Góry or Tychy. Some facilities are also located in smaller cities, such as the Burn Treatment Centre in Siemianowice Śląskie, the Trauma Hospital in Piekary Śląskie or the "Repty" Rehabilitation Centre and the Historic Silver Mine in Tarnowskie Góry (UNESCO World Heritage Site). Therefore, it is not surprising that nearly half of the Katowice residents, despite the city's very good service facilities, also use facilities located in other conurbation cities. Therefore, taking into account service connections in the conurbation, centres with different hierarchies can be distinguished (Table 2).

Table 2. Service hierarchy of the cities of the Katowice conurbation

\begin{tabular}{|l|l|}
\hline \multicolumn{1}{|c|}{ Hierarchy of the centre } & \multicolumn{1}{c|}{ Cities } \\
\hline Conurbation & Katowice \\
\hline Sub-conurbation & Bytom, Chorzów, Dąbrowa Górnicza, Gliwice, Sosnowiec, Tychy, Zabrze, \\
\hline Mini-conurbation & Będzin, Mysłowice, Ruda Śląska, Tarnowskie Góry \\
\hline Micro-conurbation & Czeladź, Jaworzno, Siemianowice Śl., Świętochłowice, Piekary Śl. \\
\hline
\end{tabular}

According to the presented hierarchy of services, Katowice covers almost the entire conurbation. In turn, sub-conurbation centres mainly affect neighbouring cities, to a limited extent. When considering sub-regional centres, certain features connecting them are clear. They are large cities with over 100,000 inhabitants, usually located peripherally in the conurbation, which makes it easier for them (despite Katowice's influence) to create their own sphere of influence in relation to smaller cities. The example of Chorzów is extremely interesting, which, despite its proximity to Katowice, is an important service centre in the central part of the conurbation, complementing the offer of the its larger neighbour. 
Mini-conurbation centres have a limited impact on neighbouring cities, but the most peripheral cities such as Będzin and Tarnowskie Góry play an important service role for rural communities in the outer conurbation zone. On the one hand, micro-conurbation centres have a very limited impact on neighbouring cities and, in addition, only in selected areas of services. At the same time, these centres were most heavily influenced by higher-level centres.

Considering the presented material, an attempt can be made to determine the factors affecting the development of service connections between conurbation cities, which are primarily: 1) varied in number and structure of service outlets in individual cities (Table 1), especially in relation to upstream, highly specialised or metropolitan services, 2) buildings continuity between neighbouring cities that occurs in many places of the conurbation, which facilitates stronger links between neighbouring cities, 3) well-developed road and transport network (tram, bus, train) and a high level of motorisation of residents (480 passenger cars per 1,000 inhabitants) enabling relatively convenient transportation by private transport and public transport between conurbation cities (SOCZóWKA, 2012) and 4) strong connections of cities regarding commuting to work or school. According to the latest data from the Statistics of Poland for 2016, only as part of the conurbation, approx. 150,000 people commuted to another city, most of them to Katowice $(60,600$ people), and to Gliwice $(14,100)$ and Sosnowiec $(10,100)$.

\section{Conclusions}

The collected information us allowed to state that it is normal for the inhabitants of the Katowice conurbation to satisfy their service needs not only in their city of residence, but also in other cities of the conurbation. As a consequence, individual cities affect other centres, though to a varying extent. These connections, especially when considering the weaker rows of connections (in Fig. 5 there are 3 strongest) have a network character. Knowledge of the functioning of service outlets - especially in the fields of education, higher education, health care and some other services, including FIRE - indicates their complementarity, which is an important element of network systems (MEIJERS, 2007b). Considering the obtained results, it is difficult to clearly determine the scale and strength of network connections within the conurbation. Therefore, it is also difficult to compare the situation of the Katowice conurbation with other polycentric regions in Europe. It simply requires further, extensive research. However, it should be noted that a certain hierarchy of cities is also visible, in terms of their size. Larger cities usually have a greater impact on the surroundings and, as indicated by GWOSDZ (2012), in economic terms they are strengthened as a result of the weakening of the economic base of some cities and an increasing dependence on better performing centres. This is the situation of the capital of the Silesian Province and the largest city of the Katowice conurbation, which has a very strong impact on virtually all cities and as the only one which has full conurbation impact. Seven other cities (Bytom, Chorzów, Dąbrowa Górnicza, Gliwice, Sosnowiec, Tychy and Zabrze) are characterised by sub-conurbation influences, which are mainly limited to neighbouring cities, and to a much lesser extent to those further away, which indicates the growing influence of the distance factor, and thus time spent travelling, especially since most of these cities have a peripheral location in the conurbation. City impacts within mini-conurbation (4 cities) and micro-conurbation (5 cities) were also identified, where the scale of influences is small and their strength weak. The main purpose for which the inhabitants go to other cities of the conurbation, is to meet their commercial and cultural needs, as well as for practising sports and recreation.

The obtained results are difficult to compare to previous studies, because they have not been implemented in this form (all services). Few studies have addressed the issue of influences only to a limited extent - education (ANALIZA POWIĄZAŃ..., 2012) or culture (KŁosowsKI, 1996). Nevertheless, in some respects they confirm the conclusions arising from other works on the Katowice conurbation (GWOSDZ, 2004, 2014; KŁOSOWSKI, 2008) indicating the dominant service role of Katowice, followed by Gliwice, Sosnowiec and the other cities: Chorzów, Tychy, Dąbrowa Górnicza, Tarnowskie Góry, Zabrze and Bytom.

\section{References}

Abbot W.F., Smith C.F. 1975. University Prestige and FirstTime Undergraduate migration in the Unite States. Sociology of Education, 48, 2: 168-185.

Alm J., Winters J.V. 2009. Distance and intrastate college student migration. Economics of Educations Review, 28, 6: 728-738.

Analiza powiązań funkcjonalnych na obszarze województwa śląskiego. 2012. Analizy RCAS, 1/2012, Wydział PSiP, Urząd Marszałkowski Województwa Śląskiego, Katowice.

Bajerski A. 2008. Możliwości wykorzystania portali społecznościowych $\mathrm{w}$ badaniu zasięgów oddziaływania szkolnictwa wyższego (na przykładzie portalu „nasza klasa”). Czasopismo Geograficzne, 79, 3: 352-363. 
Bajerski A. 2009. Badania zasięgów oddziaływania przestrzennego szkolnictwa wyższego w Polsce: Stan i perspektywy rozwoju. Czasopismo Geograficzne, 79, 3: 275-288.

Baryla E.A., Detterweich D. 2001. Student Migration: Do Significant Factors Vary by Region? Education Economics, 9, 3: 269-280.

Batten D.F. 1995. Network Cities; Creative Urban Agglomerations for the 21th Century. Urban Studies, 32: 313-327.

Belfoeld C., Morris Z. 1999. Regional Migration to and from Higher Education Institutiones: Scale, Determinants and Outcomes. Higher Education Quarterly, 53, 3: 240-263.

Borowiec M. 2000. Terytorialne pochodzenie studentów Wydziału Geograficzno-Biologicznego Wyższej Szkoły Pedagogicznej w Krakowie. [in:] Z. Zioło (ed.) Działalność człowieka i jego środowisko. Księga ku czci Profesor Marianny Kozaneckiej w 70 . rocznice urodzin. Wydawnictwo Naukowe Akademii Pedagogicznej w Krakowie, Kraków: 337-353.

Borowiec M. 2006. Pochodzenie terytorialne studentów Akademii Pedagogicznej w Krakowie. [in:] T. Komornicki \& Z. Podgórski (ed.) Idee i praktyczny uniwersalizm geografii. Geografia społeczno-ekonomiczna. Dydaktyka. Dokumentacja Geograficzna, 33, IGiPZ PAN, Warszawa, 16-20.

Bul R., Walaszek M. 2015. Dojazdy do pracy i szkół jako podstawowe kryterium delimitacji obszarów funkcjonalnych miast. Rozwój regionalny i polityka regionalna, 29: 119-138.

Burger M.J., Van der Knaap B., Wall R.S. 2013. Polycentricity and the Multiplexity of Urban Networks, European Planning Studies, 24, 4: 2-25.

Camagni R. 1993. From City Hierarchy to City Networks: Reflections about an Emerging Paradigm. [in:] T.R. Lekshmanan, P. Nijkamp (eds.) Strukture and Change in the Space Economy. Festschrift in honour of Martin Beckmann, Springer, Verlagt, Berlin: 66-87.

Campgni R, Salone C. 1993. Network Urban Structures in Northern Italy. Elements for a Theoretical Framework. Urban Studies, 30: 1053-1064.

Chojnicki Z., Czyż T. 1997. Struktura przestrzenna nauki $w$ Polsce. Bogucki Wydawnictwo Naukowe, Poznań.

Christaller W. 1933. Die Zentralen Orte in Süddeutschland, Gustav Foscher, Jena.

Christie H. 2007. Higher education and spatial (im)mobility: nontraditional students and living at home. Environment and Planning, A: 39: 2445-2463.

Czyż T., Churski P., Spychała-Szyszka H. 1996. Weryfikacja makroregionu poznańskiego $\mathrm{w}$ świetle migracji studentów. [in:] T. Czyż (ed.) Podstawy regionalizacji geograficznej. Bogucki Wydawnictwo Naukowe, Poznań: 69-95.

Dieleman F.M., Faludi A. 1998. Randstad, RhineRuhr and Flemish Diamond as One Polynucleated Macro-region. Journal of Economic and Social Geography, 89: 320-327.

Duke-Wiliams 0. 2009. The Geographies of Student migration in the UK. Environment and Planning A: Economy and Space, 41, 8: 1826-1848.

Dziewoński K. 1956. Słownik pojęć. [in:] P. George, Miasto. Państwowe Wydawnictwo Naukowe, Warszawa.

Dziewoński K., Iwanicka E. 1961. Miejsce zamieszkania (pochodzenia) słuchaczy wyższych uczelni w Polsce. Przegląd Geograficzny, 33, 1: 39-52.

Eberhardt P. 1970. Rola regionalna miast polskich $\mathrm{w}$ świetle powiązań demograficznych oraz kulturowych. Przeglad Geograficzny, 2: 297-308.

Endrukajtis J. 1957. Myszyniec [in:] Dziewoński K. et al. (ed.) Studia geograficzne nad aktywizacją małych miast.
Prace Geograficzne, Instytut Geografii PAN, PWN, Warszawa, 9: $115-165$.

Gocał T., Rakowski W. 1991. Delimitacja regionów i subregionów migracyjnych w zakresie dojazdów do pracy. Monografie i Opracowania. SGPiS, Warszawa.

Gontarski Z. 1980. Obszary metropolitalne w Polsce. Delimitacja i charakterystyka struktury przestrzennej. Biuletyn KPZK, 109.

Guzik R., Kołoś A. (ed.) 2015. Relacje funkcjonalnoprzestrzenne między ośrodkami miejskimi i ich otoczeniem $w$ województwie pomorskim. Urząd Marszałkowski Województwa Pomorskiego, Gdańsk.

Gwosdz K. 2004. Ewolucja rangi miejscowości w konurbacji przemysłowej. Przypadek Górnego Śląska (1830-2000). Uniwersytet Jagielloński, Instytut Geografii i Gospodarki Przestrzennej, Kraków.

Gwosdz K. 2012. Baza ekonomiczna i specjalizacja funkcjonalna miast konurbacji po dwu dekadach transformacji. Acta Geographica Silesiana, 11: 15-29.

Gwosdz K. 2014. Pomiędzy starq a nowq ścieżka rozwojową. Mechanizmy ewolucji struktury gospodarczej i przestrzennej regionu tradycyjnego przemysłu na przykładzie konurbacji katowickiej po 1989 r. Uniwersytet Jagielloński, Instytut Geografii i Gospodarki Przestrzennej, Kraków.

Gwosdz K., Sobala-Gwosdz A. 2012. Struktura funkcjonalna i powiązania miast konurbacji katowickiej po dwu dekadach restrukturyzacji. Przegląd Geograficzny, 84, 4: 483-507.

Hall P., Pain K. 2006. The Polycentric Metropolis. Learning from Mega-City Regions in Europe. Erthscan Sterling VA, London.

Heffner K., Gibas P. 2014. Zasięg stref oddziaływania metropolii. Studia Miejskie, 13: 9-26.

Herbst M. 2009. Tworzenie i absorpcja kapitału ludzkiego przez miasta akademickie w Polsce. Studia Regionalne i Lokalne, 10, 38: 21-38.

Herbst M. 2012. Edukacja jako czynnik i wynik rozwoju regionalnego. Wydawnictwo Naukowe Scholar, Warszawa.

Hibszer A., Powałka A., Rechłowicz M. 2009. Motywy wyboru studiów geograficznych i geologicznych na Wydziale Nauk o Ziemi Uniwersytetu Śląskiego w świetle badań ankietowych. Acta Geographica Silesiana, 6: 15-22.

Hołowiecka B. 2002. Strefa wpływu Torunia na podstawie dojazdów do pracy. Biuletyn Geograficzny, 1: 251-262.

Hołowiecka B. 2004. Oddziaływanie społeczno-gospodarcze miasta. Wydawnictwo Uniwersytetu Mikołaja Kopernika, Toruń.

Ilnicki D. 2008. Przestrzenne aspekty funkcjonowania uczelni wyższych w Polsce. [in:] T. Markowski, D. Drzazga (ed.) Rola wyższych uczelni w rozwoju społeczno-gospodarczym i przestrzennym miast. Studia KPZK PAN, 121: 33-44.

Iwanicka-Lyra E. 1969. Delimitacja aglomeracji wielkomiejskich w Polsce. Prace Geograficzne, Instytut Geografii PAN, 76.

Jeśman M. 1961. Dojazdy młodzieży do szkół a sfera wpływu Opola. Czasopismo Geograficzne, 4: 411-426.

Kłosowski F. 1996. Przestrzenne aspekty funkcjonowania placówek kulturalnych w konurbacji górnośląskiej. Geographia. Studia et Dissertationes, 20: 72-83.

Kłosowski F. 2008. Usługi [in:] M. Tkocz (ed.) Województwo śląskie. Zarys geograficzno-ekonomiczny, Wydział Nauk o Ziemi Uniwersytetu Śląskiego, Sosnowiec: 87-107.

Komornicki T., Korcelli P., Siłka P., Śleszyński P., Świątek D. 2013. Powiązania funkcjonalne pomiędzy polskimi metropoliami. SEDNO Wydawnictwo Akademickie, Warszawa.

Kremky-Saloni J. 1957. Brzeziny [in:] Dziewoński K. et al. (ed.) Studia geograficzne nad aktywizacja małych miast. 
Prace Geograficzne. Instytut Geografii PAN, PWN, Warszawa, 9: 241-285.

Krzysztofik R., Runge J., Spórna T. 2011. Delimitacja Regionu Górnośląsko-Zagłębiowskiej Metropolii „Silesia”. Sosnowiec.

Książkówna M.S. 1932. Codzienne wędrówki młodzieży szkolnej do Wielkiego Krakowa. Wiadomości Geograficzne, 10, 6: 81-82.

Kulczyńska K. 2004. Funkcjonowanie i oddziaływanie Collegium Polonicum w Słubicach jako ośrodka akademickiego. [in:] Z. Michalczyk (ed.) Badania geograficzne w poznaniu środowiska. Wydawnictwo Uniwersytetu Marii CurieSkłodowskiej, Lublin: 553-558.

Kyung W. 1996. In-migration of college students to the state of New York. Journal of Higher Education, 67, 3: 349-358.

Leszczyckiego S., Eberhardt P., Heřman S. 1971. Aglomeracje miejsko-przemysłowe w Polsce 1966-2000. Biuletyn KPZK PAN, 67.

Liszewski S. 2008. Formy i struktury przestrzenne wielkich skupisk miejskich. [in:] S. Liszewski (ed.) Geografia urbanistyczna. Wydawnictwo Uniwersytetu Łódzkiego, Łódź: 187-233.

Malisz B., Zgliński W., Heřman S., Eberhardt P. 1972. Delimitacja aglomeracji miejskich. Instytut Geografii PAN, Warszawa.

Meijers E. 2005. Polycentric urban regions and the quest for synergy: Is a network of cities more than the sum of the parts? Urban Studies, 42, 4: 765-781.

Meijers E. 2007a. From central place to network model: theory and evidence of a paradigm change. Tijdschrift voor Economische en Sociale Geografie, 98, 2: 245-259.

Meijers E. 2007b. Clones or Complements? The Division of Labour between the Main Cities of the Randstadt, the Flemish Diamond and the ReinRuhr Area. Regional Studies, 41, 7: 899-900.

Mixon F.G., Hsing Y. 1996. A regional study of net migration rates of college students. Review of Regional Studies, 26, 2: 197-209.

Molenda M. 1996. Pochodzenie terytorialne studentów studiów dziennych Szkoły Głównej Handlowej. Biuletyn Instytutu Gospodarstwa Społecznego, 39, 1: 109-121.

Ormicki W. 1932. Badania strefy wpływu w geografii miast. Wiadomości Geograficzne, 10, 6-7: 84-87.

Palonka K. 1971. Zasięg wpływu kulturalnego Tarnowa, [in.] Studia $\mathrm{z}$ geografii średnich miast $\mathrm{w}$ Polsce. Problematyka Tarnowa. Prace Geograficzne. Instytut Geografii PAN, 82: 143-161.

Potrykowska A. 1983. Współzależności między dojazdami do pracy a strukturą społeczną i demograficzną regionu miejskiego Warszawy w latach 1950-1973. Dokumentacja Geograficzna, 2.

Rakowska J. 2014. Codzienne dojazdy do pracy jako ekonomiczne kryterium rządowych klasyfikacji i delimitacji obszarów (na przykładzie USA i Kanady). Studia Regionalne i Lokalne, 57: 46-59.

Romahn-Kwiatkowska E. 1957. Lipno [in:] Dziewoński K. et al. (ed.), Studia geograficzne nad aktywizacją małych miast. Prace Geograficzne, Instytut Geografii PAN, PWN, Warszawa, 9: 167-240.

Runge J. 1991. Dojazdy do pracy w przestrzennej strukturze powiązań miast województwa katowickiego. Uniwersytet Śląski, Katowice.

Sá c., Florax R., Rietveld P. 2004. Determinations of the regional demand for higher education in The Netherlands: a gravity model approach. Regional Studies, 38, 4: 375-392.

Sitek S., Runge J., Kłosowski F., Runge A., Petryszyn J., Pytel S., Spórna T., Kurpanik M., Zuzańska-Żyśko E. 2013. Społeczno-gospodarcze i przestrzenne kierunki zmian regionalnego oraz lokalnych rynków pracy województwa śląskiego - SGP WSL, Sosnowiec.

Śleszyński P. 2013. Delimitacja Miejskich Obszarów Funkcjonalnych stolic województw. Przegląd Geograficzny, 85, 2: 173-197.

Smętkowski M. 2007. Delimitacja obszarów metropolitalnych nowe spojrzenie. [in:] G. Gorzelak, A. Tucholska (red.) Rozwój, region, przestrzeń, Ministerstwo Rozwoju Regionalnego. EUROREG, Warszawa: 215-233.

Sobala-Gwosdz A. 2007. Siła i zasięg przestrzenny oddziaływania Rzeszowa jako głównego ośrodka Polski Południowo-Zachodniej, [in.] Z. Makieła, R. Fedan, Procesy metropolizacji $\mathrm{w}$ regionie podkarpackim Rzeszów-Lwów. Biuletyn KPZK PAN, 230: 151-164.

Soczówka A. 2012. Zróżnicowanie struktury przestrzennej komunikacji miejskiej w konurbacji katowickiej, Prace Wydziału Nauk o Ziemi UŚ nr 76, Sosnowiec.

Strefy wpływów dużych miast w świetle dojazdów do pracy, 1971. Główny Urząd Statystyczny, Warszawa.

Szymańska D., Gorzelak-Kostulska E., Hołowiecka B., Hołowiecki M. 1998. Zasięg i kierunki przestrzennego oddziaływania Uniwersytetu Mikołaja Kopernika w Toruniu (na podstawie przestrzennego pochodzenia studentów. Biblioteka Główna UMK w Toruniu (manuscript).

Tomczyk H. 1987. Zmiany zasięgu przestrzennego oddziaływania łódzkiego ośrodka akademickiego (na przykładzie Uniwersytetu Łódzkiego). Acta Universitatis Lodziensis. Folia Geografhica, 8: 3-19.

Van der Knapp G.A. 2002. Stedelijke Benvegingstruimnte, over Veranderingen in Stadt an Land, The Hague, Sdu Uitgevers.

Wittlinowa H. 1937. Atlas szkolnictwa wyższego. Nasza Księgarnia, Warszawa.

Wróbel A., 1951, Regionalne zasięgi obsługi ośrodków szkolnictwa wyższego w Polsce. Przegląd Geograficzny, 31: 129-135.

Zuzańska-Żyśko E. 2016. Procesy metropolizacji. Teoria $i$ praktyka. Państwowe Wydawnictwo naukowe, Warszawa. 